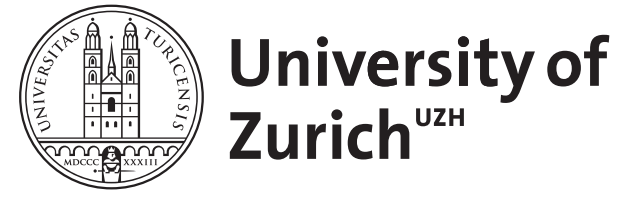

The information structure of OVS in Vedic

\author{
Viti, Carlotta
}

DOI: https://doi.org/10.1515/9783110227475.37

Posted at the Zurich Open Repository and Archive, University of Zurich

ZORA URL: https://doi.org/10.5167/uzh-43721

Book Section

Published Version

Originally published at:

Viti, Carlotta (2010). The information structure of OVS in Vedic. In: Ferraresi, G; Lühr, R. Diachronic studies on information structure. Language acquisition and change. Berlin: De Gruyter, 37-62.

DOI: https://doi.org/10.1515/9783110227475.37 


\title{
The Information Structure of OVS in Vedic
}

\author{
Carlotta Viti* \\ (Zurich)
}

\section{Introduction}

This paper discusses the OVS word order in Vedic, one of the earliest recorded Indo-European (IE) languages, dating back to the second half of the second millennium B.C. Vedic is traditionally described as an SOV language (Delbrück 1888: 15-16), and represents a crucial piece of evidence for the reconstruction of SOV as the basic word order of ProtoIndo-European (PIE) (Lehmann 1974; Watkins 1993: 85). In addition to SOV, however, all other logically possible arrangements of subject, verb, and object (SVO, VSO, OSV, OVS, and VOS) are also attested as marked variants in Vedic, and presumably were also used in PIE. Among these orders, OVS is especially rare synchronically, and subject to decay diachronically from Vedic to Classical Sanskrit.

Neither Indian grammarians nor western Indologists have completely clarified the principles underlying word order flexibility in Vedic. They occasionally ascribe syntactic fronting to emphasis. For example, Macdonell observes that the subject regularly begins the sentence in Vedic, but it may be preceded "by any other member of the sentence intended to be strongly emphasized". (1916: 284) The argument for emphasis, however, is circular: a constituent is placed in initial position as long as it is considered emphatic, and at the same time it is considered emphatic as long as it is placed in initial position. This is because emphasis, salience, and topicality are abstract concepts that cannot be directly detected in a text and that can be judged subjectively, unless they are related to an objectively observable parameter.

Some heuristic measures of topicality may be identified in specificity, humanness, definiteness, etc. of a participant and of the noun phrase de-

* I express my gratitude to the scholars who read this paper and provided me with very helpful comments: Rolando Félix Armendáriz, Eystein Dahl, Gisella Ferraresi, Leonid Kulikov, Rosemarie Lühr, Dejan Matić, Anita Steube and the reviewers of the series Language, Context and Cognition. 
noting it (cf. Myhill 1992). A singular noun phrase referring to a specific individual is usually more topical than a plural noun phrase having a generic referent. Pronouns are usually more topical than nouns, and nouns of humans are usually more topical than nouns of inanimates, according to Silverstein's (1976) Animacy Hierarchy reported in (1). Cf. also Timberlake (1977); Hopper and Thompson (1980); Mallinson and Blake (1981: 158ff); Comrie (1981: 178ff); Lazard (1984); Croft (1990: 111117), etc.:

First / second person pronouns $>$ third person pronouns $>$ proper names $>$ common nouns of human beings $>$ common nouns of animate, nonhuman beings $>$ common nouns of inanimate beings $>$ mass nouns

Of course, topicality is an utterance-level phenomenon, and therefore cannot be completely reduced to certain semantic features of the arguments. One should look at the context of each clause to establish which nominal is the topic and which is not. Beside this syntagmatic definition, however, it is undeniable that topicality also has some paradigmatic aspects. If a view of topicality as "aboutness" is adopted (i.e. if the topic is considered as being what the sentence is about), it is clear that a discourse is more often about human, animate, and specific referents than about inanimate or generic referents. Accordingly, the nominals located on the left or high part of the Animacy Hierarchy in (1) have more chances to be topics than nominals located on the right or low part of the Animacy Hierarchy. Moreover, a topic is not only definite with respect to what precedes, but is also persistent with respect to what follows (cf. Givón 1988). The repeated mention of a noun phrase entails that the denoted participant has an important role in the text.

The relative topicality of the clause arguments may be also considered as being a useful criterion to assess the level of transitivity of the clause. Despite the different views of transitivity that have been propounded, all scholars agree that in the prototypical transitive clause properties such as humanness, individuation, agentivity, and volitionality are more present in $S$ than in O. Dowty (1991) argues that the Agent Proto-Role, which largely correlates with the subject, exists independently of the event named by the verb, and causes a change of state in another participant. Instead, the Patient Proto-Role does not exist independently of the event, is causally affected by another participant, and undergoes a change of state. As far as "the defining properties of transitivity are discourse-determined" (Hopper and Thompson 1980), the degree of transitivity of a sentence may be relevant to identify the information structure carried by a particular construction.

These studies of animacy, transitivity and topicality are here used in the analysis of Vedic OVS clauses. It appears that the noun phrases that 
are semantically higher on the Animacy Hierarchy or contextually more topical (in the sense that the sentence is about them) tend to be fronted. Accordingly, OVS seems to be used when the object is more topical than the subject and the clause has a low level of transitivity. In the following sections, we will illustrate the corpus and the method used to obtain a text count of the OVS order $(\$ 2)$. We will analyze the morpho-syntactic, semantic, and pragmatic features of OVS $(\$ 3)$ with respect to different word orders $(\$ 4)$. A comparison will be made with genetically and areally unrelated languages where OVS is the basic order $(\$ 5)$. Finally, we will suggest a pragmatic explanation of the fact that certain word order patterns such as OVS diachronically decay, while others remain in the path of syntactic change from PIE to the daughter languages (\$6).

\section{Materials and method}

Our observations on the OVS word order are based on the entire RigVeda, the earliest Vedic text, even though the statistics here presented are only based on the data from book I to book V. The Rig-Veda is a collection of hymns, mainly of eulogistic character, addressed to various deities such as Indra, Agni, etc. One might object that the Rig-Veda is a poetic text, and that word order in poetry is often distorted. Although in general the basic word order of a language is more faithfully manifested in a prose text, in the specific case of Vedic it is difficult to choose between an earlier poetic text such as the Rig-Veda and a later prose text such as the Brāhmanas. The Brāhmanas contain descriptions and comments on the religious ritual; they are written in a poetic prose and in a high linguistic register, and are therefore also susceptible to display word order deviation with respect to the spoken language. Moreover, syntactic categories such as subject, object, and predicate may be represented by lexemes with very different prosodic structure, so that neither style nor meter is completely responsible for the major constituent order in the Rig-Veda.

OVS is a verb-medial order, like SVO. It has been stated that, when verb-medial clauses appear in Old Indian, the post-verbal constituent represents a sort of afterthought with respect to a clause that is already syntactically complete (Gonda 1959). This does not undermine the prevalence of the verb-final order, since the postverbal subject in OVS would represent an appositional adjunct of an OV structure. It is therefore necessary to consider the cases where $S$ itself has the function of an argument and does not represent an extra-position that is coreferential with a preverbal constituent. In this, the metric organization of the text may be of some help, since the basic syntactic structure of the clause is usually com- 
The category of modifiers does not comprise demonstratives (5), which in Vedic may have the function of third person pronouns (Whitney 1889: $\$ 495$; Macdonell 1910: \$392), and therefore function as authentic arguments. Accordingly, a verb that is preceded by an accusative demonstrative pronoun and is followed by a co-referential noun is considered as governing a preposed direct object, and is included in the group of OVS. The passage in (6), where the pre-verbal demonstrative pronoun tám is cataphorically resumed by a post-verbal proper name (indram), has been analyzed in the same way as the clause in (5). The placement in two different metric units highlights the loose linkage between the argument demonstrative and the proper name, which functions as an apposition:

(5)

(6)

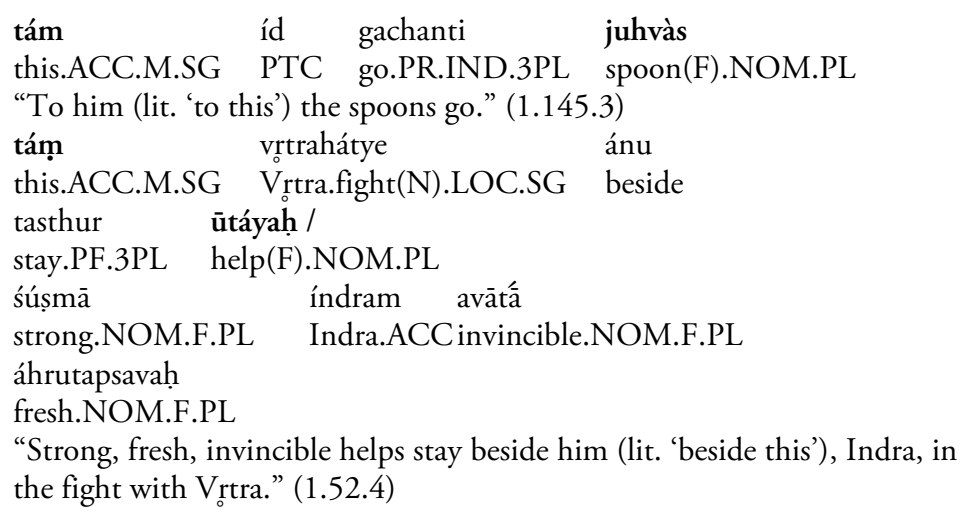

By means of such criteria, we counted 119 cases of the OVS order in books I-V of the Rig-Veda.

\section{Results}

\subsection{Formal correlates of OVS}

The subject and the object of OVS clauses are quite consistent in their morphological features, in that the subject is a plural constituent and the object is a singular constituent in 60 clauses, which correspond to $50 \%$ of cases $^{1}$. Cf. (2)-(6). This is the opposite of what we expect in a typical tran-

1 The cases with SG object and PL subject are the following: 1.5.8, 1.11.1, 1.22.20, 1.32.2, $1.32 .8,1.32 .10,1.45 .6,1.50 .1,1.52 .4,1.68 .9,1.72 .2,1.73 .7,1.85 .2,1.89 .2,1.89 .5$, $1.90 .6,1.96 .3,1.100 .13,1.122 .14,1.125 .7,1.132 .5,1.136 .7,1.141 .2,1.144 .5,1.145 .3$, $1.152 .5,1.159 .4,1.164 .7,1.164 .43,1.164 .50,1.164 .51,2.4 .2,2.18 .3,2.33 .11,2.35 .3$, 2.35.4, 3.2.5, 3.10.6, 3.26.5, 3.28.4, 3.34.8, 3.36.7, 4.2.12, 4.2.14, 4.7.4, 4.25.5, 4.31.9, 4.33.9, 4.42.1 (twice), 4.50.9, 5.8.3, 5.14.2, 5.30.13, 5.32.11, 5.48.1, 5.53.10, 5.56.2, 5.63.5, 5.82.1. 
sitive clause, where the subject is supposed to be presented as more specific than the object (Hopper and Thompson 1980). Such clauses, where $S$ is singular and $\mathrm{O}$ is plural, represent the lowest percentage $(7 \%)$ in the group of OVS clauses, as can be seen in Table 1.

\begin{tabular}{l|l} 
RV I & N (\%) \\
\hline $\begin{array}{l}\text { S: SG } \\
\text { O: SG }\end{array}$ & $29(24 \%)$ \\
\hline $\begin{array}{l}\text { S: PL } \\
\text { O: PL }\end{array}$ & $13(11 \%)$ \\
\hline $\begin{array}{l}\text { S: SG } \\
\text { O: PL }\end{array}$ & $8(7 \%)$ \\
\hline $\begin{array}{l}\text { S: PL } \\
\text { O: SG }\end{array}$ & $60(50 \%)$ \\
\hline O/S: DU & $9(8 \%)$ \\
\hline TOTAL & $119(100 \%)$
\end{tabular}

Table 1: Grammatical number of $S$ and $\mathrm{O}$ in the OVS order

Of course, the notion of "singular vs. plural" reference does not completely overlap with the notion of "specific vs. generic" reference: plural NPs may be specific, and singular NPs may be generic in reference. However, a certain correlation between singularity and specificity on the one hand, and between plurality and generality on the other may exist, in the sense that - ceteris paribus - a definite singular NP is presented as more specific than a definite plural NP, and an indefinite singular NP is presented as more specific than an indefinite plural NP. From this point of view, grammatical number may be considered as being a heuristic measure of topicality similarly to other morpho-syntactic features such as gender or case. The nominative, for example, is usually treated as correlated to agentive and topical roles in nominative-accusative languages, although strictly speaking not all nominatives and not all subjects are agents or topics.

\subsection{Semantic correlates of OVS}

The higher referentiality of the object with respect to the subject emerges if we take into account the lexical-semantic features of these noun phrases in OVS clauses. In 41 cases the object occupies a higher position than the subject on the Animacy Hierarchy reported in $(1)^{2}$. The prototypical situa-

2 The passages where $\mathrm{O}$ ranks higher than $\mathrm{S}$ on the Animacy Hierarchy are the following: 
tion is that of an $\mathrm{O}$ represented by a personal or demonstrative pronoun and of an $S$ represented by a common noun with an inanimate referent, as in (7), which represents the first instance of the OVS order in the RigVeda:

$$
\begin{array}{lll}
\text { tvắm } & \text { vardhantu } & \text { no gírah } \\
\text { you.ACC } & \text { increase.IPV.3PL } & \text { our song(F).NOM.PL } \\
\text { "May our songs increase you." } & (1.5 .8)
\end{array}
$$

From a syntactic or prosodic point of view, stressed pronouns such as tvăm "you" display the same free distribution as full-fledged nouns, and may open the clause or the verse ${ }^{3}$. The preposed object of OVS may also be the proper name of a human being or anthropomorphic god, which similarly presents a high degree of individuation, as in (4) and in (8). Here Sürya, the sun, is described as a conscious god, rather than as a natural force, as can be observed from the epithet Jātavedas lit. "the one who knows (vedas) all that is born (jätá-)".

$$
\begin{aligned}
& \text { úd u tyám jātávedasam devám } \\
& \text { up PTC that Jātavedas.ACC } \operatorname{god}(\mathrm{M}) \text {.ACC.SG } \\
& \text { vahanti ketávah } \\
& \text { bring.PR.IND.3PL } \quad \operatorname{ray}(\mathrm{M}) \text {.NOM.PL } \\
& \text { "The rays bring up the god Jatavedas." (1.50.1) }
\end{aligned}
$$

The fact that the patient is denoted by a personal pronoun or by a proper name referring to the addressee of the hymn, while the non-human referent of the agent is presented as generic, is a signal of the low transitivity of the clause. The presence of a negative operator, as in (3) and (9), or of an imperative illocutionary force, as in (7) and (10), may also decrease transitivity. It is well known that imperative clauses and negative clauses are less transitive than declarative clauses and clauses with a positive polarity (Hopper and Thompson 1980):

$1.5 .8,1.11 .1,1.32 .8,1.32 .10,1.45 .6,1.50 .1,1.52 .4,1.96 .3,1.100 .13,1.117 .19,1.125 .7$, $1.136 .7,1.144 .5,1.145 .3,1.164 .45,1.167 .4,2.4 .2,2.18 .3,2.23 .6,2.26 .4,2.33 .11$, $2.35 .3,2.35 .4,3.2 .5,3.10 .6,3.20 .1,3.31 .10,3.34 .8,3.56 .1,4.25 .5,4.31 .10,4.47 .2$, 4.50.9, 4.53.1, 5.8.3, 5.14.2, 5.30.13, 5.32.11, 5.33.5, 5.53.10, 5.56.2.

3 The "object before subject"-position is even more typical for clitic pronouns (cf. 1.105.8: sám mà tapanty abhitah sapátnìr iva párśavah "Ribs oppress me on every side like rival wives"). Clitic pronouns have been excluded from our counting, since their occurrence in the second slot of the clause (usually after a preverb) is syntactically determined by Wackernagel's Law, rather than by pragmatics. It may be argued, however, that this syntactic tendency represents the grammaticalization of the same functional principle identifiable in the preferred fronted position of stressed pronouns. 
(9)

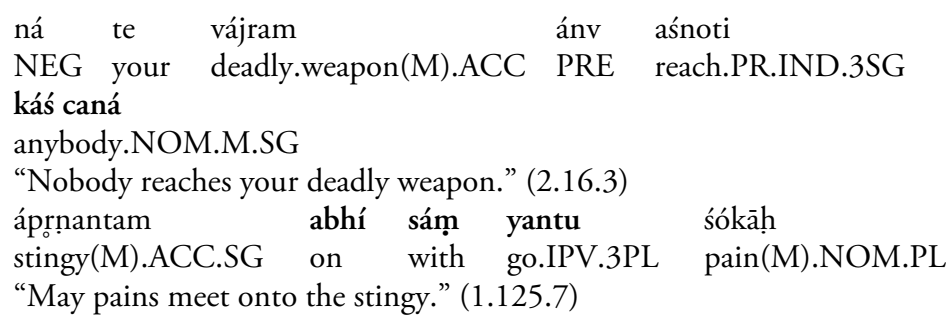

The scarce transitivity of the situation described in (10) emerges from the professional translations, where the human patient is promoted to the subject position and the inanimate agent is relegated to the status of a locative role: "Let not the liberal sink to sin and sorrow" (Griffith 1889: 87); "Die Spender sollen nicht in Sünde und Schuld fallen" (Geldner 1951: 174$)^{4}$.

One third of OVS clauses (47 occurrences, corresponding to 39\%) is taken by declarative clauses with a present indicative, which contrast with the only 3 occurrences $(2.5 \%)$ of the aorist indicative ${ }^{5}$. In Vedic, the present is used for imperfective and atelic situations, while perfectivity and telicity determine the use of the aorist (Gonda 1962). Since perfective aspect and telic actionality are exhibited by prototypical transitive clauses, the rarity of OVS clauses with an aorist verb is a further signal of low transitivity.

This also comes out if one considers the remaining OVS clauses which contain an imperfect or a perfect. Although imperfect, perfect, and aorist are indifferently used as past tenses in Old Indian, they still display dissimilar aspectual and actional values in Early Vedic, where the perfect and the imperfect denote stative or durative situations, like the present and

4 Western translations rephrase the Vedic expression also as far as negation is concerned. In Vedic we have "may pains meet the stingy", where negation has narrow scope on the object noun: áprnat- "stingy" is literally a participle of the root $p \bar{r}$ "fill" with privative a- meaning "not filling". Instead, Griffith (1889) and Geldner (1951) extend the scope of negation to the whole clause: "may the liberal not sink" etc. Accordingly, the passage in (10) presents affixal negation (cf. Bhatia 1995: 3ff), in addition to the imperative, as a transitivity decreasing factor. Sentential negation may be also observed in 3.28.4, 3.32.11, 3.56.1, 4.25.5, 4.31.9, etc. The imperative mood proper occurs in 1.122.14, 1.183.2, 2.23.6, $2.33 .11,3.10 .6,3.37 .2,4.31 .10,5.50 .3$, etc.; an imperative illocutionary force may be also conveyed by optative and subjective moods, which in Geldner (1951) are often translated as möchten-Sätze and sollen-Sätze, cf. 1.120.2, 1.136.7, 4.2.11, 4.16.1, 5.21.4, 5.30.6, 5.33.5, 5.48.1, etc.

5 The only occurrences of the aorist indicative are in 1.11.1, 4.53.3, and 5.81.2. The present indicative occurs in $1.22 .20,1.32 .8,1.32 .10,1.45 .6,1.48 .8,1.50 .1,1.89 .3,1.89 .5$, $1.90 .6,1.100 .13,1.105 .15,1.123 .6,1.144 .5,1.145 .3,1.152 .2,1.159 .4,1.164 .7$, $1.164 .51,2.16 .3,2.25 .1,2.26 .4,2.35 .4,3.3 .2,3.20 .1,3.26 .5,3.28 .4,3.34 .8,3.36 .7$, $3.56 .1,4.7 .11,4.25 .5,4.42 .1,4.42 .2,4.47 .2,4.50 .9,5.3 .10,5.8 .3,5.14 .2 ., 5.39 .5$ (twice), 5.53.6, 5.53.10, 5.63.2, 5.63.5 (twice), 5.81.2, 5.82.1. 
unlike the aorist (cf. Viti 2007: 104ff; a comprehensive discussion of tenses in the Rig-Veda can be found in a recent study of Dahl 2008). Atelic actionality is expressed by the imperfect or perfect of il "pray" (1.96.3), tap "heat" (3.31.10), duh "milk" (3.31.11), bhr "carry" (1.60.1, 4.7.4), ksar "flow" (1.84.4), jus "enjoy" (1.152.5, 1.165.2, 4.33.9), vid "know" (1.164.45, 4.26.5, 5.40.6), sad "sit" (1.65.2, 1.89.2), pü "purify" (3.2.9), yam "stretch" (4.2.14), sthä "stay" (1.52.4, 2.35.3), hve "invoke" (1.117.19), etc. In the remaining occurrences, the imperfect and the perfect mainly have a middle voice, which expresses a less transitive situation than the active voice, implying that the process takes place in the personal sphere of interests of the subject (cf. Kemmer 1993; Kaufmann 2004) ${ }^{6}$.

It may be significant that the OVS order is particularly frequent with predicates of motion, such as $i$ 'go' $(1.32 .8,1.125 .7,1.145 .3,2.35 .4$, 4.47.2, 5.53.6, 5.53.10), gam 'id.' (1.32.2, 5.56.2), car 'move' (1.32.10, $5.63 .2,5.63 .5)$, etc., as we have seen in (5) and in (10). Strictly speaking, accusative nominals selected by verbs of going are not bona fide direct objects, or at least they lack several features of direct objects. For example, they cannot be promoted to subjects of passive in Vedic, as Kulikov (2001) properly observes. From this point of view, they should not be even included in our corpus of OVS clauses. However, we included predicates of motion because their accusatives of goal do not differ from more typical accusative objects as far as word order is concerned. Owing to the relative frequency of these objects, their exclusion would make us miss a further piece of evidence indicating the low transitivity of OVS. Low transitivity is especially evident in the predicate sac 'follow' (11), where the object referent is conceived as the one who directs the motion of the subject referent:

$\begin{array}{lll}\text { tám } & \text { sacante } & \text { sanáyas } \\ \text { this.ACC.M.SG } & \text { follow.PR.IND.3PL } & \text { booty(F).NOM.PL } \\ \text { tám } & \text { dhánāni } & \\ \text { this.ACC.M.SG } & \text { treasure(N).NOM.PL } \\ \text { "Booties, treasures follow him." (1.100.13) }\end{array}$

\subsection{Pragmatic correlates of OVS}

In 59 cases, the higher salience of the object as compared to the subject is not immediately evident from lexical semantics, since $\mathrm{O}$ shows an equal or minor degree of animacy than $S$ on the Hierarchy in (1), and may have a

6 The middle voice with the imperfect and the perfect is found in $1.73 .7,1.85 .2,1.164 .5$, $1.68 .9,1.141 .2,1.164 .43,1.164 .50,3.1 .3,3.2 .5,3.31 .11,3.48 .3,4.26 .5,4.33 .9,5.32 .11$, 5.44.9, 5.81.1, etc. 
non-human referent. Nevertheless, the consideration of the entire context clarifies that $\mathrm{O}$ is more salient than $\mathrm{S}$ under a precise set of circumstances. ${ }^{7}$

First, the non-human object noun may be a metaphor of a human being or god, who is currently the topic of the discourse. In the clause illustrated in (3) "The immortals did not find the calf", the object noun vatsám "calf" is a typical image of the god Agni (cf. the passages 1.95.1 and 1.96.5), which is the addressee of the hymn, and therefore is more topical than the gods (amritäb). The latter are presented as generic entities that did not do something, rather than as specific agents. ${ }^{8}$

Second, the non-human referent of the object may be contrasted with another referent: contrast is inherently related to salience, and triggers fronting cross-linguistically (Myhill 1992: 208ff.). The example in (2) is extracted from a contrastive situation, which is rendered by means of an adversative clause in scholarly translations: "While the rain clouds vivify the earth, the flames of the sacrifice vivify the sky." (Brown 1968: 218; emphasis added) Earth and sky represent an established couple in many languages, and especially in Vedic imagery, where they often form copulative compounds such as dyấva-prthivi or instances of natural coordination such as dyaús ca prthivive ca, which imply a semantic component of contrast (Viti 2006).

Third, an object phrase may be fronted when it (or part of it) falls into the scope of focus, expressed by a concessive particle such as even, only, etc. (cf. 5.32.3 tyásya cin maható nír mrgásya vádhar jaghāna távișibhir indrah. 'Indra with his forces hit the weapon even of that mighty wild creature') or by the marker of a wh-question. In (12), for example, the object noun bráhmāni "sacred words" is modified by the interrogative pronoun kásya, and therefore is moved at the beginning of the sentence (cf. also 5.48.1):

7 The passages where $\mathrm{O}>\mathrm{S}$ can only be assessed on the basis of the context are the following: $1.22 .20,1.60 .1,1.72 .2,1.89 .2,1.89 .3,1.89 .5,1.90 .6,1.120 .2,1.122 .14,1.132 .5$, $1.141 .2,1.152 .2,1.152 .5,1.159 .4,1.164 .5,1.164 .43,1.164 .50,1.164 .51,1.165 .2$, $1.183 .2,2.16 .3,2.25 .1$ (five times), 3.2.9, 3.3.2, 3.3.11, 3.26.5, 3.28.4, 3.32.11, 3.35.5, 3.36.7, 3.37.2, 3.48.3, 4.2.11, 4.2.12, 4.2.14, 4.7.4, 4.7.11, 4.31.9, 4.33.9, 4.42.1, 4.42.2, 5.3.10, 5.21.4, 5.30.6, 5.32.3, 5.39.5 (twice), 5.40.6, 5.48.1, 5.50.3, 5.63.2, 5.63.5 (twice), 5.81.2, 5.82.1.

8 The idea that $\mathrm{O}$ rather than $\mathrm{S}$ is currently the topic of discussion is often suggested by the cumulative use of modifiers, complements or appositions for $\mathrm{O}$, as in 1.60.1: "Mātariśvan brought Bhrgu, as a gift, the glorious conveyer of oblations, banner of sacrifice, zealous messenger that immediately reaches his goal, child of two births, praised like richness", etc. Here the object váhnim "draught animal, horse that conveys oblations" (typically said of Agni) together with its attributes builds a long noun phrase consisting of 33 out of the 44 syllables of the stanza, and denotes the addressee of the hymn, which is further mentioned in the subsequent verses. Instead, the subject noun phrase is only represented by the noun mätariśvan, which decays in the following (cf. also 1.22.20, 1.89.3, and 1.89.5). 


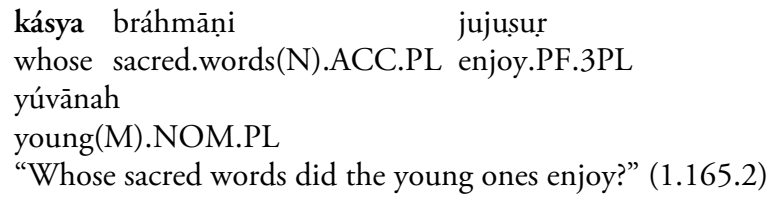

The fact that focused constituents are fronted is not at odds with the fronting of topical objects in Vedic. These ideas would be difficult to conciliate if one adopts a view of topic that is mutually exclusive with that of focus: in Lambrecht (1994), for example, a topic is the piece of information that the speaker judges to be identifiable by the hearer on the basis of the previous context, while the focus is the piece of information on which the hearer has presumably not drawn his/her attention. However, as anticipated in $\$ 1$, we consider the topic as being "what the discourse is about" (cf. Dik 1995), and this can be either definite or indefinite information. Vedic does not possess specific presentative constructions such as English there is to introduce new referents in the discourse: when a referent that is "important" (i.e. a referent that represents a persisting piece of information) is introduced, it is fronted in the same way as an important referent that conveys old information. Syntactic fronting does not occur if the new referent immediately decays.

Fourth, object fronting may be determined by numerals, as in (13). Cf. also 1.141.2 and 1.164.5. It may be argued that numerals increase the specificity and individuation of a noun phrase, in that they explicit the exact size of the referent:

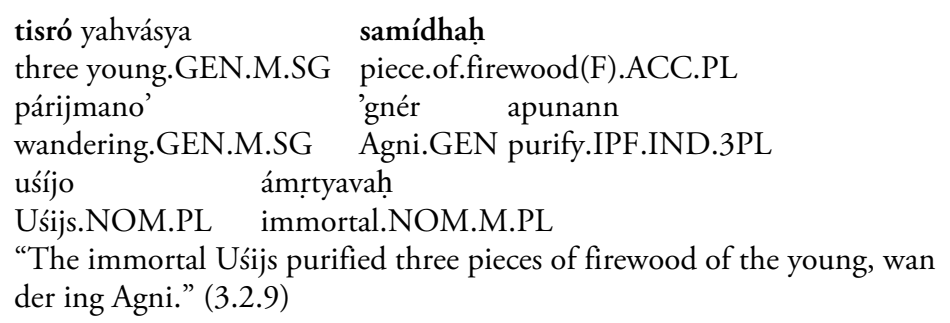

Fifth, the iteration of the object noun reveals its topic-worthiness. In (14) both $\mathrm{S}$ and $\mathrm{O}$ are represented by common nouns of inanimate items: $\mathrm{S}$ refers to the "rivers" (sindhavab), and O refers to a "sweet substance, mead, honey" (mádhu). In the three verses of the stanza, however, the subject changes, and only the noun-adjective mádhu persists: 


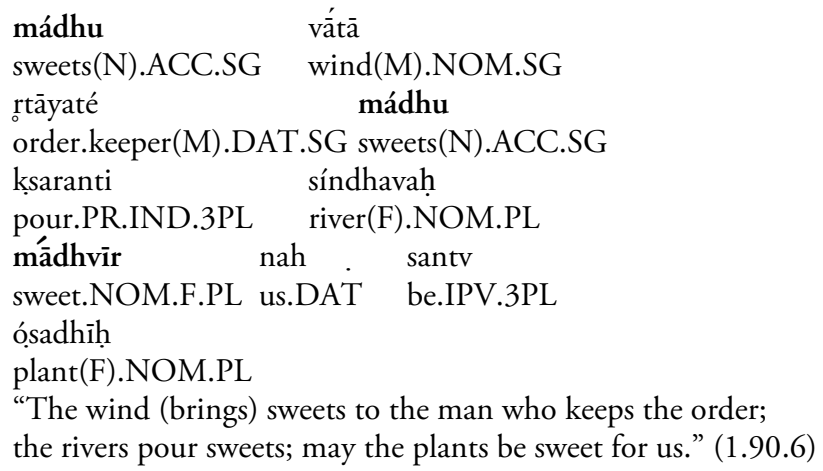

The object noun mádhu is also iterated in stanzas 7 and 8: "Sweet (mádhu) may be the night and the dawns, full of sweets (mádhumat) the terrestrial atmosphere; sweet (mádhu) may be Father Heaven to us. Full of sweets (mádhumān) may be the tree for us, full of sweets (mádhumān) the sun; sweet (mádhvīh) may be our milk-cows." The fact that a mass noun such as mádhu may be topicalized shows the importance of taking into account discourse pragmatics to investigate the principles underlying word order. In (15), the name of an inanimate object (yajñá- "sacrifice") appears contextually even more topical than the name of an animate subject (devăh "gods"), as indicated by the figura etymologica:

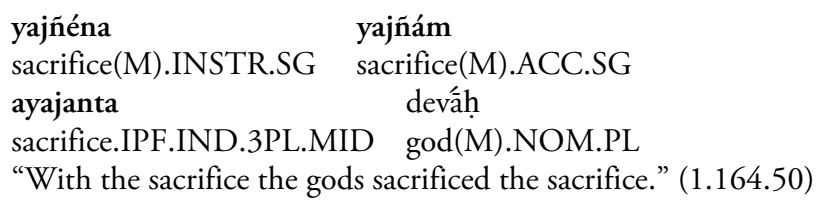

The same passage recurs in RV 10.90.16. Scholars acknowledge that this hymn ushers in a new conceptualization of the sacrifice, which is no longer seen as a means to worship the gods, but rather as an independent deity who deserves to receive its own worship (Sani 2000: 248-49). When the object is involved in a figura etymologica, it is syntactically fronted even without a precise lexical repetition. Cf. 1.159.4 "The refulgent poets weave a web for ever new in the sky, in the sea" (návyam-navyam tántum á tanvate divi samudré antáh kaváyaḥ suditáyah); 1.183 .2 "may this song attend your glory with glory (vápur vapusyấ sacatām iyám gình); 2.25 .1 "He with his seed spread forth beyond another's seed, whomever Brahmanaspati takes for his friend" (jäténa jātám áti sá prá sarsịte yám-yam yújam krṇuté bráhmaṇas pátih); 4.2.11 "May the wise discern discernment and nondiscernment of men, like straight and crooked backs of horses" (cittim ácittịn cinavad ví vidvấn prọsthéva vìtà vịjinà ca mártān); 4.7.11 "When, thirsty, (consuming) the food with its thirsty (flame), he grows, the young 
Agni makes the thirsty (Wind) his messenger" (trșú yád ánnā trṣúnāa vavákșa trșúm dütám kṛ̣ute yahvó agníh), etc.

These factors are often cumulative. In (16), for example, the object noun phrase, denoting "threads" (tántūn), is fronted with respect to the human subject. Two pragmatic principles may underlie this fronting: the object is specified by a numeral (saptá "seven") and forms a figura etymologica with the verb, which is equally derived from the root tan "to tend":

$$
\begin{array}{llll}
\text { vatsé } & \text { baskáyé } & \text { 'dhi } & \text { saptá } \\
\text { calf(M).LOC.SG } & \text { yearling.LOC.M.SG } & \text { above } & \text { seven } \\
\text { tántūn } & \text { ví } & \text { tatnire } & \\
\text { thread(M).ACC.PL } & \text { PRE } & \text { weave.PF.MID.3PL } \\
\text { kaváya } & \text { ótavă } & \text { u } & \\
\text { sage(M).NOM.PL } & \text { weave.IF } & \text { PTC } &
\end{array}
$$

"Above the yearling calf the sages have woven the seven threads to form a web" (1.164.5).

On the whole, a situation where the object ranks higher than the subject in salience because of its lexical-semantic or discourse-pragmatic features appears in 100 out of 119 passages, which correspond to $84 \%$ of the analyzed cases of OVS, as can be seen in Table 2:

\begin{tabular}{l|l} 
RV I & $\mathrm{N}(\%)$ \\
\hline $\mathrm{O}>\mathrm{S}$ & $100(84 \%)$ \\
\hline $\mathrm{S}>\mathrm{O}$ & $19(16 \%)$ \\
\hline TOTAL & $119(100 \%)$
\end{tabular}

Table 2: Information structure of OVS in Rig-Veda I-V

\section{Different word orders in the Rig-Veda}

The peculiar character of the OVS order especially emerges insofar as it is compared with the semantic and pragmatic features typically associated with alternative word order patterns. Here we report the first example occurring in the Rig-Veda for each type of major constituent order where subject, object, and verb are explicitly represented, in patterns such as SOV (17), SVO (18), VSO (19), OSV (20), and VOS (21). The first OVS clause has been reported already in (7): 
(17)

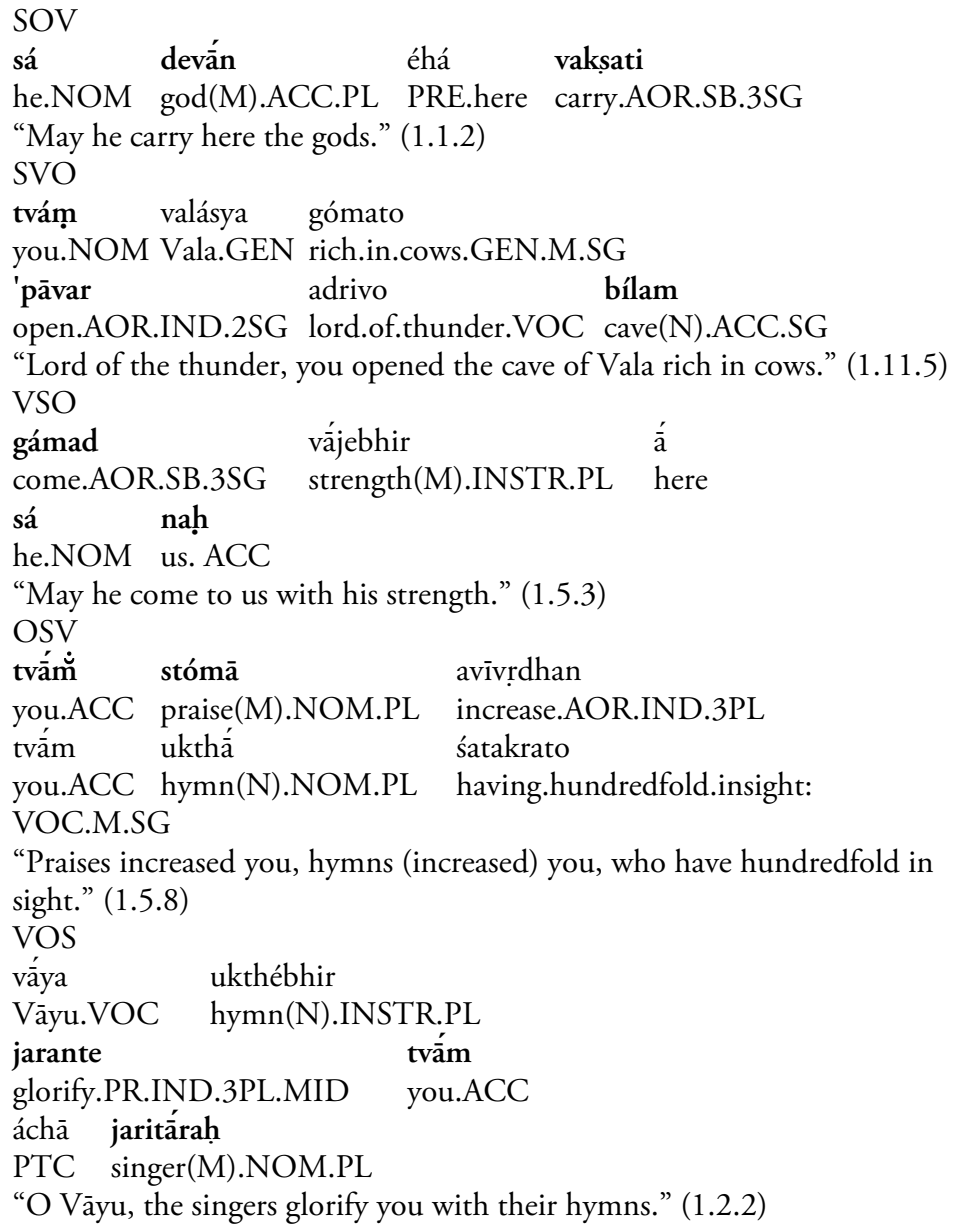

All orders where the subject precedes the object, such as SOV (17), SVO (18), and VSO (19), present the aorist stem, which - as we have seen in $\$ 3.2$ - typically expresses perfectivity and telicity, and therefore characterizes highly transitive clauses. Instead, the orders where the object comes first typically display either a present tense, as in the VOS clause in (21), or an imperative mood, as in the OVS clause in (7) (for the aorist tense in OSV, see below). We mentioned that the durative actionality of the present and the irrealis modality of the imperative indicate a low degree of transitivity. This is confirmed if we take into account the ranking of $S$ and $\mathrm{O}$ on the Animacy Hierarchy in (1).

In SOV and SVO, the subject usually ranks higher than the object on the Animacy Hierarchy. In the SOV order reported in (17), $S$ is a third 
person pronoun (sáb "he") and $\mathrm{O}$ is a common noun (devấn "gods"). Similarly, in the SVO order in (18), O is a common noun (bilam "cave") and $S$ is a second person pronoun (tvám "you").

It appears that SOV differs from SVO in the relative topicality (in the sense of relative ranking on the Animacy Hierarchy) of the object with respect to the subject. In SVO, a high difference in topicality exists between the subject and the object, and the object is commonly not topical at all, that is, it is located on the very low part of the Hierarchy. In (18), O is represented by the common noun of an inanimate item such as bilam "cave". In SVO, V behaves as a borderline between the preposed topical information and the postposed non-topical information. The idea that non-topical material is relegated in the post-verbal position has also been assessed in the major constituent order of Ancient Greek (Dik 1995: 111ff; Matić 2003). In the Rig-Veda, the information structure conveyed by SVO can be considered the mirror-image of the information structure of OVS, the other verb-medial pattern, analyzed in $\$ 3$. We have seen that a striking difference in the pragmatic status of subject and object exists in OVS, where the subject is the non-topical constituent. In the example of OVS in (7), $\mathrm{O}$ is a second person pronoun (tvăm "you"), while $S$ has an inanimate referent, such as girah "songs".

Unlike in SVO, in SOV the object is assigned a certain degree of topicality, that is, it usually refers to human or animate items, which are represented higher than inanimate items on the Hierarchy. In (17), the animate referents of the object, i.e. the gods, persist as topical participants in this hymn: cf. stanza 4 "he goes among the gods" (sá id devésu gachati); 5 "he, the god, may come here with the gods" (devó devébhir à gamat).

A different situation can be identified in OSV, the other verb-final construction. On the one hand, in this order $\mathrm{O}$ outranks $S$ in topicality, similarly to what happens to other object-initial orders. The OSV clause "Praises increased you" in (20), for example, is coordinated with a similar OVS clause such as "May our songs increase you" reported in (7). On the other hand, transitivity is relatively higher in OSV than in OVS. In our examples, (7) shows an imperative, while (20) has the aorist, which per se is more typical of subject-initial orders than of object-initial orders. In an analysis of the OSV word order in the Rig-Veda (Viti 2009), we observed that in the majority of cases the subject has a human referent like the object in this order, as can be seen in the second OSV clause that is attested in the Rig-Veda: "Indra the singers ... glorified" (indram id gäthino ... anüsata). Thus, OSV is similar to other object-initial orders such as OVS in presenting the object as more topical than the subject, but at the same time the difference in topicality between $\mathrm{S}$ and $\mathrm{O}$ is not as dramatic in OSV as it is in OVS. 
The two verb-initial patterns, VSO and VOS, can be also conceived as mirror-images of each other. In VOS (21), the object pronoun tvăm "you" is clearly more topical than the subject common noun jaritărab "singers". VOS shares this pragmatic situation with other orders such as OSV and OVS, where the object is placed before the subject. Instead, the consideration of the context clarifies that $\mathrm{S}$ outranks $\mathrm{O}$ in topicality in the VSO word order in (19). Here we have a third person subject (sáb "he") and a first person object ( $n a$ h "us"), so that the latter seems to rank higher from a purely semantic point of view, that is, considering the ranking of the Animacy Hierarchy (1). However, it is enough to take a look at the whole sentence, reported in (22), to see that the third person subject occurs in an anaphoric chain, and is more persisting and topical than the first person object. Pragmatic studies acknowledge that, in case of a clash between lexical semantics and discourse pragmatics, the latter prevails in orienting the word order of a noun phrase. "If a language should be discovered where some order facts appear to be describable in semantic terms, but in a given context a certain pragmatic principle would predict an alternative order, the pragmatic principle will most surely win out. The overall governing principles would thus be pragmatic, and order would only appear to be semantically based in the norm because of the large majority of cases where semantic and pragmatic principles converge on the same structure." (Payne 1992: 3-4):

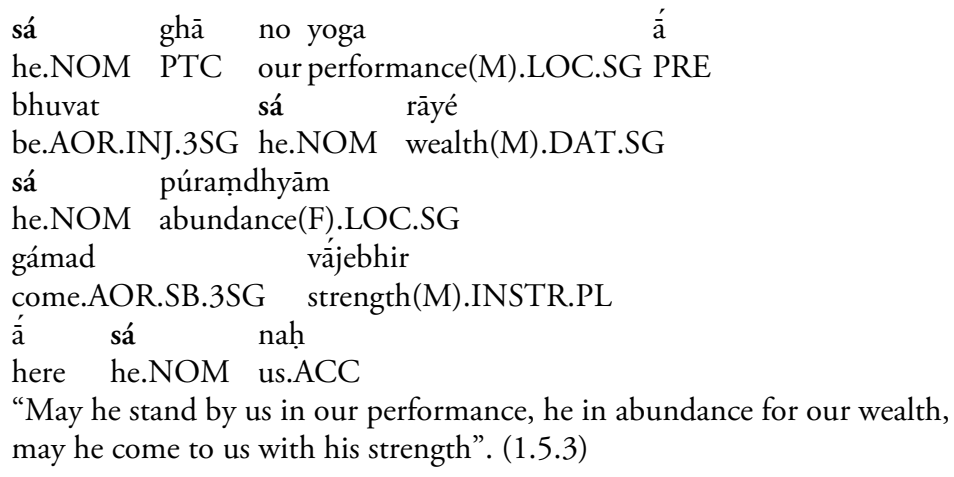

This information structure puts VSO on the same plan of the other orders where the subject is placed in front of the object, such as SOV and SVO, in which the subject is also more topical than the object. However, verbinitial orders are substantially different from other patterns, in that here the verb is really the most salient piece of information of the clause. A predicate may be considered a salient piece of information when attention is given to the way the denoted action takes place, by means of modifiers 
or complements that add some details of that action. By means of such adverbs the composer may insist on a verbal concept ${ }^{9}$.

In the VSO order in (19), both $S$ and $\mathrm{O}$ are pronouns, which represent highly accessible topics. The imperative illocutionary force of the subjunctive mood gamad "may he come" lays emphasis on the predicate, and the instrumental complement vájebhibh "with strength" lingers on the description of the manner of coming. Similarly, in the VOS order in (21), the object is a pronoun, and the noun with the function of the subject, jaritârab "singers", does not add anything new to the information of the preceding verb jarante "they sing". The fact that $S$ is built on the same root jr "sing" as the verb indicates that $S$ is completely predictable. Here the verbal action is highlighted by the addition of the instrumental complement ukthébhib "with hymns", which portrays the manner of singing. The instrumental case has the function of a manner adverb qualifying verbal action in Old Indian. In the rubric entitled "instrumental, the howcase”, Speyer (1886: \$63) observes: "It is always used when it is wanted to express the circumstances, instruments, means, ways, properties accompanying the action and qualifying it. In other terms, the instrumental has the duty of telling the how of the action or state, expressed by the verb or verbal noun, it depends on." The fact that adverbials draw attention to verbal action may explain the cross-linguistic finding, noted by Bubenik (1991: 19), that adverbials are typical of the VSO order. This may also explain why two similar constructions, quoted by Bubenik (1991: 20) and here reported as examples (23) and (24), may present two different word orders:

à gachanti $\quad \overline{i m} \quad$ ávasā
PRE come.PR.IND.3PL him.ACC aid(N).INSTR.SG
“They come to him with aid." (1.85.11)
pári șīm nayanti
PRE him.ACC lead.PR.IND.3PL
"They lead him around.” (1.95.2)

The verb-initial clause in (23) is accompanied by an instrumental complement (ávasa "with aid") that specifies the circumstances of the action of coming, similarly to (19) and (21) above. The idea that verb-initial pat-

9 More specific conditions of the verb-initial order may vary from language to language. In Vedic and in Homeric Greek this order seems to be used when the sentence has a "thetic" function, that is, when the subject belongs to the focus, rather than to the topic, of the clause (Viti 2008). In other languages, initial verbs may have a text-connecting function, as Reis (2000) and Lühr (2007a) show for German and Old Frisian, respectively. In Old Frisian, conditional clauses with initial verbs are found in the middle of a discourse, and are distinguished from conditional clauses with generic relative pronouns, which occur at the beginning of a text section. This phenomenon may be considered a development peculiar to the Germanic languages. 
terns are related to the salience of the predicate is supported by Bubenik's (1991: 22) data, according to which Vedic favors VO in jussive clauses. In the same vein, Klein (1991: 130) states that verb-initial clauses in Vedic are often found with performative predicates, such as "I call", "we proclaim", etc., where the utterance of a first-person subject is identical to the performance of the action denoted by the verb. Command and first person can be considered independent signals of verbal salience. The salience of the verb in verb-initial orders may be related to the fact that verbs are accented in Vedic only when they are placed in the first position of a metric or syntactic unit (Macdonell 1916: 466-468). Prosodic prominence is a formal manifestation of importance.

Table 3 summarizes the pragmatic situations associated with the different word orders in Vedic. The cases where the predicate is the main focus of attention are signalled by the symbol $+\mathrm{V}$; the cases where this does not occur have the symbol $-\mathrm{V}$. The marks $>$ and $>>$ represent the relative ranking of arguments, in agreement with Givón (2001: 93), who uses these symbols to illustrate the different topicality of the agent and of the patient in active, inverse, passive, and anti-passive constructions: ${ }^{10}$

\begin{tabular}{c|l|c} 
ORDER & ARGUMENTS & PREDICATE \\
\hline SOV & $\mathrm{S}>\mathrm{O}$ & $-\mathrm{V}$ \\
\hline SVO & $\mathrm{S}>>\mathrm{O}$ & $-\mathrm{V}$ \\
\hline OSV & $\mathrm{O}>\mathrm{S}$ & $-\mathrm{V}$ \\
\hline OVS & $\mathrm{O}>>\mathrm{S}$ & $-\mathrm{V}$ \\
\hline VSO & $\mathrm{S}>\mathrm{O}$ & $+\mathrm{V}$ \\
\hline VOS & $\mathrm{O}>\mathrm{S}$ & $+\mathrm{V}$
\end{tabular}

Table 3: Information structure of the major constituent orders

Table 3 shows that the relative ranking of $S$ and $O$ is less dramatic when they are adjacent, i.e. in SOV, OSV, VSO, and VOS. Instead, when they

10 Particularly, >> signals that the arguments not only have a different prominence in the context, but often belong also to different lexical-semantic classes or to different positions of the Animacy Hierarchy in (1). Since OVS often contains subjects and objects that differ both semantically and pragmatically (cf. \$3), the single arrow ( $>$ ) in Table 2 has been more properly presented here as double arrow $(>>)$ in comparison with the information structure of the other word orders. 
are separated by the verb, in SVO and OVS, they differ much more in salience. Since in Vedic the syntactic function of an argument is indicated by its grammatical case, word order (particularly verb-medial word order) is clearly not used to disambiguate subject and object. To the extent that arguments that are semantically and pragmatically similar are placed closer to each other than dissimilar arguments, word order is iconically arranged in this language.

\section{Typological parallels}

The OVS order is rarer than its symmetrical pendant, the SVO order. In the first book of the Rig-Veda, for example, we counted 45 occurrences of OVS and 132 occurrences of SVO. This tallies with the distribution of OVS cross-linguistically: a basic OVS order is so rare that it was assumed not to exist for a long time, until it was identified in Hixkaryana (25) and in other languages of the Amazon basin by Derbyshire and colleagues:

$$
\begin{aligned}
& \text { Hixkaryana (Derbyshire 1985: 31; cf. 97ff.) } \\
& \text { kuraha yonyhoryeno biryekomo } \\
& \text { bow he made: it boy } \\
& \text { "The boy made a bow." }
\end{aligned}
$$

More generally, typological research found that all orders where the object precedes the subject (OSV, OVS, and VOS) are recessive with respect to the orders where the subject precedes the object (SOV, SVO, and VSO; cf. Greenberg 1966: 77). In the sample of Mallinson and Blake (1981: 148), 85 out of 100 languages abide by the principle of subject precedence, and only 4 languages contravene it (the remaining languages have a free word order, where no basic pattern can be identified from the sources). In a larger sample (Dryer 2005: 330-333) consisting of 1228 languages, subject precedence is represented by 1017 languages $(83 \%)$, while object precedence appears in 39 languages (3\%) (the remaining 172 languages lack a dominant word order).

Comrie motivates the principle of subject precedence with the universal correlation between subject and agent, which typically is presented as more topical (i.e. as anaphorically more definite and cataphorically more persisting) than the object in transitive clauses. "Explanations for the predominance of word orders where the subject precedes the object seem more likely to have a psychological basis, in terms of the salience of the agent in the agent-action-patient situation, and the high correlation between semantic agent and syntactic subject." (1981: 20)

The semantic motivation of word order is obscured in many languages, where the overlap between agent and subject determines the exten- 
sion of the word order used in prototypical transitivity to different situations, independently of the degree of agentivity of the subject. This semantic basis, however, can be observed both in Vedic and in Hixkaryana. In Vedic, where word order is not fixed, we have seen that the object precedes the subject in the unusual case of an object referring to a more topical participant than the subject. Hixkaryana, where the establishment of OVS is a relatively recent phenomenon, has an ergative alignment (thus, PVA would be a more appropriate description of this basic word order). It has been observed that ergative constructions often derive from passive constructions with the agent expressed (Mallinson and Blake 1981: $109 \mathrm{ff}.)^{11}$. In the passive, the patient is the real topic of discourse.

The parallel with the languages of the Americas, where a pragmatic pattern topic - comment or rheme - theme has been often identified (cf. Tomlin and Rhodes 1979; Mithun 1987; Payne 1987, etc.), suggests not to consider merely definiteness as being the driving factor of syntactic fronting in Vedic, as proposed for example by the Prague School. In the Functional Sentence Perspective of the Prague School, theme and rheme correspond to old information and new information, and topicality is identified with giveness (Firbas 1966). This view is based on a number of modern European languages, where the first constituent of a sentence is usually more definite or lower in communicative dynamism than the subsequent constituents.

Instead, when we observe that the most topical piece of information comes first in Vedic, we think of the nominal referring to the participant that ranks higher in humanness, specificity, agentivity, and persistence in the discourse. The Rig-Veda contains a quite limited range of issues, inherent to prayer, sacrifice, priests, etc., so that both the subject and the object of a transitive clause often convey given information, and identifiability is not sufficient to predict word order (cf. Lühr 2004). Moreover, even a noun phrase conveying new information may be fronted, as long as it is the most salient argument of the clause in Vedic. For example, the passage "The rays bring up the god Jatavedas" in (8) represents the incipit of a hymn, so that the pre-verbal object jätávedasam necessarily conveys new information, while the post-verbal subject ketávab "rays" are easily inferable from the mention of the sun, on the basis of a part-whole relation. In this case, the placement of the word for the whole in front of the

11 In the case of Hixkaryana, the ergative alignment derives from a passive nominalization, where the patient is encoded as a pre-verbal genitive and the agent appears after the verb as the complement of an adposition. For example, the clause "the enemy destroys the city" would be originally expressed as a nominalized expression such as "the city's destruction by the enemy" (Gildea 1997). 
word for the part is consistent with the Animacy Hierarchy, but is inconsistent with the "old before new" principle.

Under this perspective, a topical referent is one that has a prominent position not only, or not necessarily, in the previous part of the discourse, but also in the following. Lexical iteration manifests such prominence: in the Rig-Veda, both content-words and function-words that are iterated are typically placed in the initial position of the linear string. This matches the situation commonly found in non-IE language provided with a flexible word order. In languages such as Ute and Papago, the pre-verbal position is devoted to focused, discontinuous, contrastive, and indefinite noun phrases (Myhill 1992: 209). Indefinite noun phrases, however, are only fronted as long as they persist in the subsequent discourse. Payne (1987: 796) finds out that a substantial amount of post-verbal indefinite noun phrases in Papago are not mentioned again in the discourse. Armendáriz (this volume) notices that the focus relation is coded by the sentence initial position in Warihío.

The fact that languages such as Hixkaryana (Carib), Ute (UtoAztecan), Papago (id.), Warihío (id.), etc. belong to non-IE domains should not obscure their similarities with the early IE languages as far as word order is concerned. All these languages, where word order is not subject to strictly syntactic rules, mainly have an oral tradition.

A diachronic change is likely to have occurred from the stage of the early IE languages, where fronting was due to topicality in the sense of specificity, animacy, and persistence, to the stage of the modern IE languages, where old information usually precedes new information. The change probably started from enclitic pronouns, which are inherently definite expressions and, at the same time, tend to appear in long chains, so that their referents are contextually important. Since enclitic pronouns grammaticalize their position earlier than full-fledged noun phrases (Lambrecht 1994: 201-202), the association between definiteness and preverbal position easily entrenches. This probably determined the reinterpretation of pre-verbal arguments as definite arguments, as captured by the tenets of the Prague School.

\section{Conclusions}

We have discussed word order in Early Vedic, and particularly the appearance of the pattern OVS in the Rig-Veda. Traditionally, Vedic is assigned a basic SOV word order, which is assumed to reflect the consistent SOV word order of PIE. Alternative arrangements such as OVS are wounded up as exceptions due to poetic license. This interpretation, however, does 
not capture the generalization that OVS occurs in a precise set of pragmatic situations, where an inanimate agent affects a human patient, independently of the morphological or metrical structure of the arguments. Accordingly, OVS clauses display a low degree of transitivity, which is also indicated by the common association with an irrealis modality and with predicates expressing states, rather than actions, or durative events. We do not deny the marked status of OVS in Vedic, which is also relatively rare in our corpus. Rather, we contest its interpretation: in our opinion, OVS should be considered marked because the pragmatic functions it conveys have less chance to appear in discourse.

In Vedic, different word orders are associated with different pragmatic situations, according to two main principles. First, the fronted argument is more specific, animate, and topical (in SOV, SVO, and VSO, the subject is more topical than the object; in OSV, OVS, and VOS, the opposite occurs). The relation between syntactic fronting and perceptual salience has cross-linguistic parallels, and is also demonstrated by cognitive studies, according to which material placed in the initial position of a string plays a privileged role in processes of attention and memory (Gernsbacher 1990). Second, subject and object tend to be adjacent when they are semantically and/or pragmatically similar (in SOV, OSV, VSO, and VOS), while they are usually separated by the verb when they are different from each other (in SVO and OVS).

Synchronically, the idea that different word orders are not synonymous is compatible with an approach like that posited in Construction Grammar (cf. Goldberg 1995). Although Construction Grammar strictly speaking does not take word order into account, its assumptions may be extended to situations where word order is syntactically free and is used to convey meaning, as in the case of Vedic.

Diachronically, the marked pragmatic conditions in which OVS appears in the Rig-Veda make it predictable that this word order would decay, together with the other patterns where the subject is preceded by the object, such as OSV and VOS. The IE languages grammaticalize the basic word orders SOV, SVO, and VSO, where the subject is more topical than the object, as in typical transitive clauses. 


\section{Abbreviations}

$\mathrm{A}=$ agent $\mathrm{ACC}=$ accusative $\mathrm{AOR}=$ aorist $\mathrm{DAT}=$ dative $\mathrm{DU}=$ dual; $\mathrm{F}$ = feminine; GEN = genitive; GER = gerund; IE = Indo-European; IND = indicative; INJ = injunctive; INSTR = instrumental; IPF = imperfect; IPV = imperative; $\mathrm{LOC}=$ locative; $\mathrm{M}=$ masculine; $\mathrm{MID}=$ middle; $\mathrm{N}=$ neuter; $\mathrm{NEG}=$ negation $; \mathrm{NOM}=$ nominative $; \mathrm{O}=$ object $\mathrm{P}=$ patient $; \mathrm{PIE}=$ Proto-Indo-European; $\mathrm{PF}=$ perfect; $\mathrm{PL}=$ plural; $\mathrm{PR}=$ present; $\mathrm{PRE}=$ preverb; $\mathrm{PTC}=$ particle; $\mathrm{PVA}=$ patient-verb-agent; $\mathrm{SB}=$ subjunctive; QUOT = quotative; $S=$ subject; $S G=$ singular; $\mathrm{V}=$ verb; $\mathrm{VOC}=$ vocative.

\section{References}

Bhatia, T. (1995): Negation in South Asian languages. Patiala: Indian Institute of Language Studies.

Brown, N. (1968): Agni, Sun, Sacrifice, and Vāc: a sacerdotal ode by Dīrghatamas. Journal of American Oriental Studies 88, 199-218.

Bubenik, V. (1991): Nominal and pronominal objects in Sanskrit and Prakrit. In: Hans H Hock (ed.), 19-30.

Comrie, B. (1981): Language universals and linguistic typology. Chicago: The University of Chicago Press.

Croft, W. (1990): Typology and universals. 2nd edition. Cambridge: Cambridge University Press.

Dahl, E. (2008): Time, Tense and Aspect in Early Vedic Grammar. A TimeRelational Approach to the Morphosyntax-Semantics Interface. PhD Thesis: University of Oslo.

Delbrück B. (1888): Altindische Syntax (=Syntaktische Forschungen 5). Halle: Verlag der Buchhandlung des Weisenhauses.

Derbyshire, D. (1985): Hixkaryana and linguistic typology. Arlington: The University of Texas.

Dik, H. (1995): Word order in Ancient Greek. A pragmatic account of word order variation in Herodotus. Amsterdam: Gieben.

Dowty, D. (1991): Thematic proto-roles and argument selection. Language 67, 547-619.

Dryer, M. (2005): Order of subject, object, and verb. In: M. Haspelmath., M. Dryer, D. Gil and B. Comrie (eds.), The World Atlas of Language Structure, 330-333. Oxford: Oxford University Press. 
Firbas, J. (1966): On defining the theme in functional sentence analysis. In: Travaux linguistique de Prague, 267-80.

Geldner K. F. J. (1951): Der Rig-Veda aus dem Sanskrit ins Deutsche übersetzt und mit einem laufenden Kommentar versehen von Karl Friedrich, I-III; IV Index by Nobel J. (1957). Cambridge (Mass.): Harvard University Press.

Gernsbacher, M. A. (1990): Language comprehension as structure building. Hillsdale: Erlbaum.

Gildea, S. (1997): Introducing ergative word order via reanalysis. Word order change in the Cariban family. In: J. Bybee, J. Haiman and S. Thompson (eds.), Essays on language function and language type dedicated to T. Givón, 145161. Amsterdam and Philadelphia: John Benjamins.

Givón, T. (1988): The pragmatics of word order: predictability, importance and attention. In: M. Hammond, E. Moravcsik, and J. Wirth (eds.), Studies in syntactic typology, 243-84. Amsterdam and Philadelphia: John Benjamins.

Givón T. (2001): Syntax. Revised edition, Volume II. Amsterdam and Philadelphia: John Benjamins.

Goldberg, A. (1995): Constructions: A Construction Grammar approach to argument structure. Chicago-London: The University of Chicago Press.

Gonda, J. (1958): Syntax and verse structure in the Veda. Indian Linguistics 20, $35-43$.

Gonda, J. (1959): On amplified sentences and similar structures in the Veda. In: Four studies in the language of the Veda. The Hague: Mouton, 7-70.

Gonda, J. (1962): The aspectual function of the Rigvedic present and aorist. The Hague: Mouton.

Greenberg, J. (1966): Some universals of grammar with particular reference to the order of meaningful elements. In: J. Greenberg (ed.), Universals of language. 2nd edition, 73-113. Cambridge (Mass.): MIT Press.

Griffith, R. (1889): The hymns of the Rig-Veda. Delhi: Motilal Banarsidass.

Hock, H. (ed.) (1991): Studies in Sanskrit syntax. Delhi: Motilal Banarsidass.

Hopper, Paul and S. Thompson (1980): Transitivity in grammar and discourse. Language 56, 251-99.

Kaufmann, I. (2004): Medium und Reflexiv. Ein Studium zur Verbsemantik. Tübingen: Niemeyer.

Kemmer, S. (1993): The middle voice. Amsterdam and Philadelphia: John Benjamins.

Klein, J. (1991): Syntactic and discourse correlates of verb-initial sentences in the Rig-Veda. In: H. H. Hock (ed.), 123-143.

Kulikov, L. (2001): The Vedic -ya- presents. PhD dissertation: Leiden University. 
Lambrecht, K. (1994): Information structure and sentence form. Topic, focus and the mental representations of discourse referents. Cambridge: Cambridge University Press.

Lazard, G. (1984): Actance variations and categories of the objects. In: F. Plank (ed.), Objects. Toward a theory of grammatical relations, 269-292. London: Academic Press.

Lehmann, W. P. (1974): Proto-Indo-European syntax. Austin-London: University of Texas Press.

Lühr, R. (2004): Thematische Rollen und Kasus: Zu Agens und Patiens beim Passiv im Altindischen. In: A. Steube (ed.), Grammatik und Kontext: Zur Interaktion von Syntax und Semantik und Prosodie bei der Informationsstrukturierung. Linguistische Arbeitsberichte 81, 99-126.

Lühr, R. (2007a): Bedingungssätze in altfriesischen Rechtstexten. In: R. Bremmer, S. Laker and O. Vries (eds.), Amsterdamer Beiträge zur älteren Germanistik. Band 64. Amsterdam: Rodopi, 213-238.

MacDonell, A. (1910): Vedic grammar. Straßburg: Trübner.

MacDonell, A. (1916): A Vedic grammar for students. London: Oxford University Press.

Mallinson, G. and B. Blake (1981): Language typology. Amsterdam: New Holland.

Matić, D. (2003): Topic, focus, and discourse structure. Ancient Greek word order. Studies in Languages 27, 573-633.

Mithun, M. (1987): Is basic word order universal? In: Tomlin, R. (ed.), Coherence and grounding in discourse, 281-328. Amsterdam and Philadelphia: John Benjamins.

Myhill, J. (1992): Typological discourse analysis. Oxford: Blackwell.

Payne, D. (1987): Information structuring in Papago narrative discourse. Language 63, 783-804.

Payne, D. (1992): Introduction. In: Payne, D. (ed.), Pragmatics of word order flexibility. Amsterdam and Philadelphia: John Benjamins.

Reis, M. (2000): Anmerkungen zu Verb-erst-Satz-Typen im Deutschen. In: R. Thieroff et al. (eds.), Deutsche Grammatik in Theorie und Praxis, 215-227. Tübingen: Niemeyer.

Sani, S. (2000): Rgveda. Le strofe della sapienza. Venezia: Marsilio.

Schäufele, S. (1991): Verb-medial clauses in Vedic: some theoretical implications. In: H. H. Hock (ed.), 177-196.

Silverstein, M. (1976): Hierarchies of features and ergativity. In: R. Dixon (ed.), Grammatical categories in Australian languages, 112-171. Canberra: Australian Institute of Aboriginal Studies. 
Speyer, J. S. (1886): Sanskrit Syntax. Leyden; repr. 1973, Delhi: Motilal Banarsidass.

Timberlake, A. (1977): Reanalysis and actualization in syntactic change. In: C. Li (ed.), Mechanisms of Syntactic Change, 141-177. Austin and London: University of Texas Press.

Tomlin, R. and R. Rhodes (1979): An introduction to information distribution in Ojibwa. Chicago Linguistics Society 15, 307-320.

Viti, C. (2006): AND in the early Indo-European languages. Archivio Glottologico Italiano 91, 129-165.

Viti, C. (2007): Strategies of subordination in the Rig-Veda. Milano: Angeli.

Viti, C. (2008): The verb-initial word order in the early poetry of Vedic and Homeric Greek. In: K. Jones-Bley, M. Huld, A. Della Volpe and M. Robbins Dexters (eds.), Proceedings of the 19th Annual UCLA Indo-European Conference (Los Angeles, November 2nd-3rd 2007), Selected Papers, 89-111.

Viti, C. (2009): A quantitative analysis of the OSV word order in Vedic. In E. Rieken and P. Widmer (eds.), Pragmatische Kategorien. Form, Funktion und Diachronie, 307-322. Wiesbaden: Reichert.

Watkins, C. (1993): Proto-Indo-Europeo. In: A. Giacalone Ramat and P. Ramat (eds), Le lingue indoeuropee, 45-90. Bologna: Il Mulino.

Whitney, W. (1889): Sanskrit Grammar, 2nd edition, Cambridge (Mass.): Harvard University Press. 